Screen JA, Simmonds I. (2010). The central role of diminishing sea ice in recent Arctic temperature amplication. Nature 464: 1334-1337.

Veillette J, Mueller DR, Antoniades D, Vincent WF. (2008). Arctic epishelf lakes as sentinel ecosystems: past, present and future. J Geophys Res-Biogeosciences 113: G04014.
Vincent WF. (1988). Microbial Ecosystems of Antarctica. Cambridge University Press: Cambridge UK, pp 304.

Vincent WF, Whyte LG, Lovejoy C, Greer CW, Laurion I, Suttle CA et al. (2009). Arctic microbial ecosystems and impacts of extreme warming during the International Polar Year. Polar Science 3: 171-180.

\title{
Dangerous shifts in ocean ecosystem function?
}

\author{
Ove Hoegh-Guldberg
}

The ISME Journal (2010) 4, 1090-1092; doi:10.1038/

ismej.2010.107; published online 8 July 2010

One of the unique characteristics of our planet is that $71 \%$ of its surface is covered by water. This life-nurturing ocean has an overridingly important role in determining the physical, chemical and biological characteristics of Earth and is, in many ways, the 'heart and lungs' of our planet. Damaging the ocean will place Earth and our future in jeopardy and hence must be avoided. Although there is considerable uncertainty about how key planetary services provided by the ocean will change in the future, there are growing signs that conditions in the world's oceans have shifted significantly away from where they have been for millions of years. Evidence is also mounting that these changes are having profound impacts on the marine ecosystems with potentially serious consequences for all life on our planet. Given this, reducing human emissions of greenhouse gases to zero must be our number one International priority over the next few decades.

\section{Unprecedented physical and chemical change}

The ocean has a disproportionately large role in Earth's climate. Not only is more than $85 \%$ of the energy trapped by the enhanced greenhouse effect absorbed by the ocean, but $30-40 \%$ of the carbon dioxide emitted by human activities dissolves into the oceans (Bindoff et al., 2007). The ocean has consequently reduced the impact of human emissions on Earth's atmosphere and terrestrial ecosystems. The added energy and carbon dioxide has, however, caused fundamental changes in the physical and chemical properties of the ocean. The average temperature of the upper layers of the ocean has increased by $0.6{ }^{\circ} \mathrm{C}$ over the past century and average $\mathrm{pH}$ has decreased by 0.1 units (Doney et al., 2009). Changes in temperature have been 2-3 times greater in polar regions, leading to the rapid loss of Arctic sea ice and an accelerated melting of landlocked ice sheets in Greenland and western Antarctica. As the volume of the ocean has expanded, average global sea level rise has accelerated $\left(0.013 \pm 0.006 \mathrm{~mm}\right.$ per year ${ }^{2}$, Church and White, 2006) and is currently $3.3 \pm 0.4 \mathrm{~mm}$ per year (1993-2006). Empirically based projections place sea levels $0.5-1.2 \mathrm{~m}$ higher than today by 2100 , which will put enormous pressure on coastal ecosystems as well as human communities and infrastructure.

Human activities have already pushed the conditions of the ocean outside the limits of where they have been for millions of years (Bindoff et al., 2007; Hoegh-Guldberg and Bruno, 2010). Although change has been a characteristic of Earth throughout its history, recent anthropogenically driven climate change has been extremely rapid and is comparable in scale and rate to that associated with four out of five mass extinction events (Ward, 2007). As seen in periods of slower change (for example, the ice age transitions) biological systems trail the current rate of physical and chemical change, with little or no evidence that they are adapting sufficiently to the current rapid shift in conditions. Consequently, ocean ecosystems are beginning to change fundamentally, putting crucial ecosystem goods and services at risk and ultimately threatening the food and livelihoods of hundreds of millions of people.

\section{Marine ecosystems are now in uncharted waters}

Warming of the upper layers of the ocean has led to an increased stratification of the water column, which has implications for nutrient cycles and consequently the productivity of marine ecosystems from the polar to tropical regions. Nutrient-poor 'ocean deserts' have increased in the Pacific and Atlantic Oceans by 6.6 million $\mathrm{km}^{2}$ over the past decade, primarily due to the heat-generated stratification of the water column and loss of nutrients in the upper layers of the ocean in these regions (Polovina et al., 2008). These changes have contributed to the $6 \%$ decline in ocean productivity reported since the 1980s (Gregg et al., 2003). Observations increasingly support the notion that ocean 
ecosystems will become less productive as we warm the atmosphere and ocean (Behrenfeld et al., 2006). Changes in ocean circulation are also linked to decreasing oxygen concentrations as well as an alarming increase in the spread of deepwater anoxia and 'dead zones' across the world (Diaz and Rosenberg, 2008).

Changes in temperature are also influencing the ratio of photosynthesis to respiration, and consequently net primary productivity. The photosynthetic activities of microbes within the plankton respond more slowly to temperature than do respiratory rates, leading to reduced net primary productivity. Increasing temperatures are also influencing other components of the plankton. Invertebrate larvae, for example, develop faster at higher temperatures (Hoegh-Guldberg and Pearse, 1995). These changes have the potential to produce mismatches between the timing the appearance of larvae in the water column and their food sources such as phytoplankton. Increased developmental rates and decreased larval periods will also reduced connectivity between marine populations with consequences for the replenishment of marine populations and ecosystems, and ultimately human resources such as fisheries.

Rapid changes in conditions are also affecting habitat complexity from polar to tropical regions. Key habitat-creating organisms such as corals, sea grasses and mangroves face enormous pressure from both global and local stresses. In the case of reefbuilding corals, increasing temperatures are causing increasingly frequency and severity of mass coral bleaching and mortality, while steadily acidifying ocean waters are decreasing the ability of corals to build their calcareous skeletons and consequently maintain reef structures (Hoegh-Guldberg et al., 2007). Together with local factors such as overfishing and declining water quality, these changes have resulted in a $1-2 \%$ per year decline in coral abundance and a reduction in coral calcification of 15\% since 1990. These impacts on corals and other marine calcifiers are putting at risk hundreds of thousands of species that use coral reefs for their habitat. Impacts of climate change and ocean acidification on habitat creating species are not restricted to tropical waters. Similar issues are appearing along temperate coastlines where the contraction of kelp forests is also reducing the availability of habitats for thousands of dependent species. Similarly, the rapid decrease in the extent of summer sea ice in the Arctic is putting pressure on associated biodiversity from ice algae to polar bears (Wegner et al., 2010).

Marine microbial systems provide approximately $50 \%$ of Earth's net primary production (Field et al., 1998) and are critically important to global nutrient cycles (Arrigo, 2005). These systems also underpin globally important processes such as the biological 'pump' that transports massive amounts of carbon from the sunlit surface to the ocean's interior. Despite their importance, however, our current understanding of how climate change and ocean acidification will affect marine microbial processes is relatively undeveloped. Improving our knowledge and understanding of these changes and their potential impacts will become increasingly important if not vital as we navigate the uncharted waters of rapid anthropogenic climate change.

Planetary emergency: a compelling case for deep and immediate action on emissions

It may seem far-fetched to some that human activities are causing such large-scale and fundamental changes to the world's oceans. However, the rapidly accumulating evidence and understanding of these changes is largely irrefutable (Bindoff et al., 2007; Hoegh-Guldberg and Bruno, 2010) and should be of serious concern given the ramifications of these changes for the well-being of humans everywhere. In acknowledging the problem, however, we have no other choice but to mitigate the source of the problem (that is, reduce greenhouse gas emissions) and adapt to the consequences of climate change that are already 'in the pipeline'. Mitigation of the problem relies heavily on identifying safe levels of $\mathrm{CO}_{2}$ and other greenhouse gases in the atmosphere. In this regard, there is compelling evidence that atmospheric $\mathrm{CO}_{2}$ of 450 p.p.m. and average global temperatures that are $+2{ }^{\circ} \mathrm{C}$ above those of the preindustrial period are dangerous for a wide array of planetary components from coral reefs and Southern Ocean ecosystems to the stability of the Greenland and Antarctic ice sheets (Hoegh-Guldberg et al., 2007; McNeil and Matear, 2008; Naish et al., 2009; Pollard and DeConto, 2009; Rockström et al., 2009; Hoegh-Guldberg and Bruno, 2010).

Aspiring to stabilize atmospheric $\mathrm{CO}_{2}$ concentrations at 450 p.p.m. requires global emissions to be reduced to less than $10 \%$ of today's level by 2050, which means a reduction in global emissions of $3-4 \%$ from 2010 onwards for the next 30 years (Meinshausen et al., 2009). While it may seem an enormous and ambitious task, inaction is not an option given the scale and seriousness of the planetary scale risks involved. Current estimates of the cost of achieving this target are not excessive and involve the sacrifice of a few percent of global GDP growth over the next 3-4 decades (IPCC, 2007). Pressure to adopt this pathway is heightened by the fact that we are unlikely to be able to adapt successfully to future scenarios in which atmospheric carbon dioxide rises beyond 450 p.p.m.

There is little doubt in the minds of many that we are at a crossroad regarding facing up to and responding to anthropogenic climate change. Given the scale and rapidity of the changes, however, time is fast running out. At the current annual increase in atmospheric $\mathrm{CO}_{2}$ (>2 p.p.m. per year) we will exceed 450 p.p.m. within the next 30 years. This will produce major challenges for human communities as they struggle to understand and manage ocean conditions that are completely novel and which are changing in rapid and unpredictable ways. Given their central role in how this future will unfold, there is an urgent need 
to increase our understanding of the response of marine microbial ecosystems to climate change. Given the strong evidence, however, that we are fundamentally changing Earth's 'heart and lungs', there is no longer any excuse for international community not to pursue deep and rapid cuts in the use of fossil fuels and other greenhouse gas emitting sources. If we continue to ignore this evidence, we will place our planet, and the future of ourselves and our children, in extreme jeopardy.

O Hoegh-Guldberg is Director of the Global Change Institute, University of Queensland, St Lucia, Queensland, Australia

E-mail: oveh@uq.edu.au (www.coralreefecosystems.org; www.climateshifts.org)

\section{References}

Arrigo K. (2005). Marine microorganisms and global nutrient cycles. Nature 437: 349-355.

Behrenfeld M, O’Malley R, Siegel D, McClain C, Sarmiento J, Feldman G et al. (2006). Climate-driven trends in contemporary ocean productivity. Nature 444: 752-755.

Bindoff NL, Willebrand J, Artale V, Cazenave A, Gregory J, Gulev S et al. (2007). Observations: oceanic climate change and sea level. In: Solomon S, Qin D, Manning M, Chen Z, Marquis M, Averyt K, Tignor M and Miller $\mathrm{H}$ (eds). In Climate Change 2007: The Physical Science Basis. Contribution of Working Group I to the Fourth Assessment Report of the Intergovernmental Panel on Climate Change. Cambridge University Press: Cambridge, UK and New York, NY, USA.

Church J, White N. (2006). A 20th century acceleration in global sea-level rise. Geophys Res Lett 33: L01602.

Diaz R, Rosenberg R. (2008). Spreading dead zones and consequences for marine ecosystems. Science 321: 926.

Doney S, Fabry V, Feely R, Kleypas J. (2009). Ocean acidification: the other $\mathrm{CO}_{2}$ problem. Annu Rev Marine Sci 1: 169-192.
Field C, Behrenfeld M, Randerson J, Falkowski P. (1998). Primary production of the biosphere: integrating terrestrial and oceanic components. Science 281: 237-241.

Gregg W, Conkright M, Ginoux P, O’Reilly J, Casey N. (2003). Ocean primary production and climate: global decadal changes. Geophys Res Lett 30: 1809.

Hoegh-Guldberg O, Bruno JF. (2010). The impact of climate change on the world's marine ecosystems. Science 328: 1523-1528.

Hoegh-Guldberg O, Mumby PJ, Hooten AJ, Steneck RS, Greenfield P, Gomez E et al. (2007). Coral reefs under rapid climate change and ocean acidification. Science 318: 1737-1742.

Hoegh-Guldberg O, Pearse JS. (1995). Temperature, food availability, and the development of marine invertebrate larvae 1. Integr Comp Biol 1995.

IPCC (2007). Synthesis report. Contribution of Working Groups I, II and III to the Fourth Assessment Report of the Intergovernmental Panel on Climate Change, CW Team, RK Pachauri and A Reisinger (eds). Intergovernmental Panel on Climate Change: Geneva, Switzerland.

Meinshausen M, Meinshausen N, Hare W, Raper S, Frieler $\mathrm{K}$, Knutti R et al. (2009). Greenhouse-gas emission targets for limiting global warming to $2^{\circ} \mathrm{C}$. Nature 458 : 1158-1162.

McNeil B, Matear R. (2008). Southern Ocean acidification: a tipping point at 450-ppm atmospheric $\mathrm{CO}_{2}$. Proc Natl Acad Sci 105: 18860-18864.

Naish T, Powell R, Levy R, Wilson G, Scherer R, Talarico F et al. (2009). Obliquity-paced Pliocene West Antarctic ice sheet oscillations. Nature 458: 322-328.

Pollard D, DeConto R. (2009). Modelling West Antarctic ice sheet growth and collapse through the past five million years. Nature 458: 329-332.

Polovina J, Howell E, Abecassis M. (2008). Ocean's least productive waters are expanding. Geophys Res Lett 35: L03618.

Rockström J, Steffen W, Noone K, Persson A, Chapin F, Lambin E et al. (2009). A safe operating space for humanity. Nature 461: 472-475.

Ward P. (2007). Under a Green Sky: Global Warming. The Mass Extinctions of the Past, and What they Mean for our Future. Smithsonian Books/Collins: New York.

Wegner C, Forest A, Forwick M, Frey K, Mathis J, Michel C et al. (2010). Arctic in rapid transition. Arctic Ocean Sciences Board/International Arctic Science Committee (AOSB/IASC), $34 \mathrm{pp}$.

\title{
Ammonia oxidation: different niches for bacteria and archaea?
}

\author{
Christa Schleper
}

The ISME Journal (2010) 4, 1092-1094; doi:10.1038/ ismej.2010.111; published online 15 July 2010

Ammonia oxidation, the first step of nitrification, has been known to be performed by certain groups of chemolithoautotrophic proteobacteria for more than a hundred years. The recent discovery of homologs of ammonia monooxygenase genes in archaea and the cultivation of archaeal ammonia oxidizers has radically changed this view, indicating 